\title{
Poverty and chronic diseases in Asia: challenges and opportunities
}

\author{
Prabhat Jha MD DPhil, Zhengming Chen MD DPhil
}

$\mathrm{T}$ he economic rise of China and India is likely nothing less than a fundamental realignment of the global order. ${ }^{1}$ Current income growth in these countries is paired with a rapid demographic and epidemiologic transition. The aging population and the increasing prevalence of chronic noncommunicable diseases (such as heart attack, stroke, diabetes mellitus, respiratory diseases and cancer) pose considerable challenges to the weak health care systems in these countries. The emerging threats from chronic diseases have not just major health implications, but also economic and financial costs. ${ }^{2}$ Here, we argue that much of the chronic disease occurring in Asia is avoidable, that chronicdisease control reduces poverty and finally that creation of epidemiologic and clinical evidence that enables such control is a global, not only an Asian, challenge.

\section{Avoidable adult mortality in Asia}

Currently, about 27 million deaths occur each year in South and East Asia: 7 million among those under 30 years of age, Io million in middle-aged people (Table I and Table 2) ${ }^{3,4}$ and another ro million among those 70 years and older. The individual years of life lost are greatest for death at young ages, but even among middle-aged people, a premature death means 20 to 25 years of productive life lost, often years that would have been spent as the head of a household. Trends in mortality over the past 200 years in some areas of the world have indicated that reductions in death before old age could be achieved more widely. Specifically, death at young ages (below 30 years of age) could become a rare occurrence, and death in middle age (30 to 69 years) need no longer be common. ${ }^{5,6}$

Marked reductions in child mortality in China and India over the past few decades have meant that the vast majority of those born in these countries now can expect to reach middle age. Today, there are an estimated I.3 billion adults 30-69 years of age (Table I) in South and East Asia, and at these ages nearly $70 \%$ of deaths are from noncommunicable diseases, with communicable, maternal and nutritional conditions accounting for $20 \%$ of deaths, and injuries accounting for another 10\%.

The Disease Control Priorities Project ${ }^{7}$ reviewed over 300 health interventions and found proven, feasible, affordable and cost-effective interventions that can reduce the risk of premature death from chronic diseases in middle age (Table 2). A substantial number of adult deaths still result from tuberculosis and AIDS, such that effective tuberculosis treatment and avoidance of HIV-I infection are also important.

\section{Key points of the article}

- The rise of chronic diseases in South and East Asia (most importantly in China and India) has major health and poverty implications and presents a substantial challenge for governments

- Of the 8 million deaths from chronic disease that occur each year in Asia among those 30-69 years of age, many are avoidable

- A handful of highly cost-effective interventions exist for the control of chronic disease. Among these, cessation of tobacco use by the region's 500 million smokers is key to reducing burdens from vascular, respiratory and neoplastic diseases and from tuberculosis

- An Asian partnership with Western governments and institutions to create better interventions and to monitor the evolution of the great epidemic of chronic disease could have global scientific benefits

\section{Avoiding the poverty traps from chronic disease}

Rapid economic growth in Asia does not, per se, guarantee rapid improvements in health outcomes. Indeed, the health gaps between urban and rural areas and between poor and rich people are widening. It is easy for households to spend too well and not wisely on chronic disease care. Historical lessons from countries in the Organisation for Economic Cooperation and Development are clear: public financing of clinical services is essential to maintain costs and to ensure quality and equitable access. ${ }^{8}$ Historically, China and India have spent far too little on health, partly because health has not been seen as a "productive" part of the economy ${ }^{8}$ and also because of low national income. Income growth in China and India means that they are now able to spend more from the public purse. Recent economic growth has led to both countries announcing plans to expand public funding of health care: India to address its historically low spending (less than $\mathrm{I} \%$ of gross domestic product for public spending on health) and China to reverse its disastrous withdrawal of rural cooperative health insurance in the I9gos, when, almost overnight, more than Ioo million rural Chinese lost health care coverage.

Both countries have adopted the United Nations goals for

From the Centre for Global Health Research (Jha), St. Michael's Hospital, University of Toronto, Toronto, Ont.; and the Clinical Trial Service Unit and Epidemiological Studies Unit (Chen), University of Oxford, Oxford, UK 
reducing child and maternal mortality by 2015 . The case for encompassing chronic diseases in efforts to expand health care is 4 -fold. First, these are major killers that can rob households of a lot of years of good health. Second, there are highly cost-effective interventions, as noted above and detailed in the Disease Control Priorities Project). ${ }^{7}$ Third, despite the notion that these are "diseases of affluence," much of the burden of chronic disease and its risk factors are concentrated among the poor. For example, smoking prevalence among illiterate Chinese and Indian males is nearly 50\% higher than among their literate counterparts. ${ }^{9}$ Household tobacco use in India is associated with low birth weight and premature birth, as well as with economic hardship arising from increased hospital admissions. ${ }^{10}$ Adult ill health is a major reason for households sliding into poverty. ${ }^{11}$ Fourth, there is evidence that productive adult health has been central to economic growth in the region, partly through increases in savings rates, along with better productivity. ${ }^{8}$

\section{Four cost-effective approaches to control chronic disease in Asia}

As examples of highly practicable interventions that reach the poor and that reduce premature mortality, we consider 4 approaches, drawing on information gathered by the Disease Control Priorities Project. ${ }^{7}$

\section{Tobacco control}

In China and India, as in most low-income countries, death in middle age increases in relative importance as the effects of smoking increase. However, tobacco kills differently in different parts of South and East Asia. In China, the leading causes of death from smoking are chronic lung disease and lung cancer, with a noted excess also of tuberculosis deaths but much lower heart disease. ${ }^{12}$ In India, the leading causes of death from smoking are tuberculosis and heart disease, with relatively less lung cancer. ${ }^{13}$ Unless there is widespread cessation of smoking, some roo million of China's 300 mil-

Table 1: Population and deaths (in millions) in South and East Asia* by cause among people $30-69$ years of age, for $2001 \uparrow$

\begin{tabular}{lccc}
\hline Variable & Men & Women & All \\
\hline $\begin{array}{l}\text { Total population } \\
\text { Deaths }\end{array}$ & 661 & 636 & 1297 \\
$\quad$ All causes & 6.1 & 4.2 & 10.3 \\
$\begin{array}{l}\text { Communicable, } \\
\text { maternal and }\end{array}$ & & & \\
$\begin{array}{l}\text { nutritional } \\
\text { conditions }\end{array}$ & 1.2 & 0.8 & 2.0 \\
$\begin{array}{l}\text { Noncommunicable } \\
\text { diseases }\end{array}$ & 4.1 & 2.9 & 7.0 \\
$\quad$ Injuries & 0.8 & 0.5 & 1.3 \\
\hline
\end{tabular}

${ }^{*}$ China and India account for more than $70 \%$ of the total population in these geographic regions.

†Adapted, with permission of the World Bank Group, from Jha and Anderson. ${ }^{3}$ Original data source: Lopez and associates. ${ }^{4}$ lion male smokers and about 40 million of India's roo million male smokers will eventually die from tobacco-related causes.

Many countries in the Organisation for Economic Cooperation and Development have seen substantial declines in smoking deaths over the past 2 decades; for example, lung cancer deaths among men 30-44 years of age have fallen by nearly $80 \%$ in the United Kingdom, ${ }^{14,15}$ a change attributable chiefly to marked increases in cessation. Also, in the countries of the Organisation for Economic Co-operation and Development, more than $30 \%$ of the adult population are exsmokers, in contrast to only $2 \%$ in India, $9 \%$ in China and ${ }^{15} \%$ in Thailand. ${ }^{16}$ Thailand is far ahead of China and India, as it has had a much more comprehensive tobacco-control strategy. In China, smoking cessation has increased only since about 1998, when the first scientific reports that smoking was killing large numbers of Chinese people appeared in the popular press. ${ }^{12} \mathrm{~A}$ considerable number of tobacco deaths over the next half century could be prevented by encouraging current smokers to quit smoking. Reducing the uptake of smoking by children will yield benefits chiefly in the second half of the 2ist century. ${ }^{14,15}$ Cost-effective measures to encourage cessation and reduce uptake include higher taxes, which are vastly underused in Asia. For example, bidis, the most commonly smoked form of tobacco in India, have historically had low taxation rates. Other effective measures include restrictions on public smoking, government support for quit-smoking clinics, better public information about

Table 2: Mortality* (in millions) in South and East Asia from selected causes, among people $30-69$ years of age, for $2001 \dagger$

\begin{tabular}{|c|c|c|c|}
\hline Cause of death & Men & Women & All \\
\hline Cancer & 1.1 & 0.8 & 1.9 \\
\hline $\begin{array}{l}\text { Ischemic heart } \\
\text { disease }\end{array}$ & 1.0 & 0.6 & 1.6 \\
\hline Stroke & 1.0 & 0.4 & 1.4 \\
\hline $\begin{array}{l}\text { Respiratory } \\
\text { diseases }\end{array}$ & 0.5 & 0.4 & 0.9 \\
\hline Tuberculosis & 0.6 & 0.3 & 0.9 \\
\hline AIDS‡ & 0.2 & 0.05 & 0.3 \\
\hline $\begin{array}{l}\text { All } \\
\text { noncommunicable } \\
\text { diseases plus } \\
\text { tuberculosis and } \\
\text { AIDS }\end{array}$ & 4.9 & 3.3 & 8.2 \\
\hline
\end{tabular}

*Avoidance of disability is also important. Mortality does not capture all illnesses, specifically missing neuropsychiatric and musculoskeletal diseases. However, the correlation of mortality with morbidity for most major diseases is quite strong. Moreover, it is important to note that measurement error in disability estimates is much greater than in mortality estimates and often exceeds the desired change in health outcomes. For example, a health policy planner may desire a $10 \%$ improvement in diabetes outcomes, but if measurement error exceeds $10 \%$ in the health outcome measure, the planner will not know if the intervention has worked. Since death is a clear and usually measurable event, restricting analyses to mortality should reduce measurement error in health policy-making. For more details, including estimates of disability-adjusted life years in the region, see reference 3. †Adapted, with permission of the World Bank Group, from Jha and Anderson. ${ }^{3}$ Original data source: Lopez and associates. ${ }^{4}$

fNewer data from direct epidemiologic studies suggest that deaths from AIDS may be a magnitude lower than the indirect estimates from the Global Burden of Disease study. 
smoking hazards, and prominent warning labels on cigarette and bidi packs and packaging. ${ }^{12}$

\section{Hepatitis $B$ vaccination}

An estimated 0.4 million deaths from liver cancer occur each year in South and East Asia, many of these due to chronic infection from hepatitis B. Universal immunization with hepatitis B vaccine, which was implemented in China in 2002 but has not yet been undertaken in India, is highly cost-effective and could avert up to $90 \%$ of the estimated I.5 million deaths from liver cancer that will otherwise occur among those born in the region in the year 2000. ${ }^{17}$ For those who are already infected, however, vaccination will not help. Strategies are needed to reduce cofactors, such as exposure to aflatoxins (toxic compounds produced by certain strains of fungi, which can damage the liver) and alcohol.

\section{Screening for and vaccination against cervical cancer}

Nearly 150000 women die from cervical cancer each year in South and East Asia, ${ }^{4}$ and almost all of these deaths are caused by human papillomavirus. Vaccines for this viral infection have now been introduced in Western countries. Making these widely accessible at reasonable cost to adolescent girls would avert a very large proportion of future deaths from cervical cancer among young adult women. Ensuring that all adult women undergo at least one Papanicolaou test or human papillomavirus screening for early cervical cancer with referral if the result is positive - would be an effective way to reach older women who will not benefit from the new vaccines. ${ }^{17}$

\section{Low-cost combination drug therapy for vascular disease}

There is considerable evidence that simple combinations of cheap drugs can be highly effective in reducing mortality among the millions of adults in South and East Asia who already have some form of vascular disease or diabetes. ${ }^{18}$ For example, among patients with a history of occlusive vascular disease such as stroke or heart attack, use of acetylsalicylic acid, a statin and an antihypertensive drug could reduce the annual risk of major recurrence by about two-thirds; the 10year risk of death or readmission to hospital is about $50 \%$ if people go untreated but only $\mathrm{I} 6 \%$ if they receive daily treatment with 3 or 4 drugs. All of these drugs are inexpensive and could easily be packaged into "polypills" or "generic risk pills" for widespread use. ${ }^{19}$ Indeed, China's success in ensuring widely accessible tuberculosis therapy with several drugs serves as a model of how simple drug therapy for vascular disease could be introduced in the region.

\section{The globalization of evidence}

Rapid globalization of goods and services also means that unique opportunities are arising to enhance global knowledge about the control of chronic disease. Already, large-scale "mega" trials conducted in China have had major impact on clinical practice in the West, ${ }^{20}$ and India's biotechnology sector and its generic drug manufacturers are booming. However,
Western academic institutions and industry still enjoy a comparative advantage in research. If this advantage could be appropriately levered, global knowledge would surely advance.

Consider a practical example. High blood cholesterol is a major risk factor for heart disease worldwide. A previous prospective study in China showed that the positive relation between risk of heart disease and total cholesterol levels in the blood continues down to at least $3 \mathrm{mmol} / \mathrm{L}$ (i.e., well below the range generally studied in Western population ${ }^{21}$ ). These findings (suggested earlier by Rose in his classic paper of $1985^{22}$ ) have only recently widened our perspective on what might be regarded as "normal" in Western populations. Indeed, they have also affected the way in which lipid-lowering therapy is managed in high-risk patients. ${ }^{23}$ Similarly, much of what we know about chronic disease will be greatly enhanced by better scientific research in epidemiological studies currently under way in China and India. ${ }^{24,25}$ Moreover, we can learn much from a better understanding of how information about risks is created and then communicated to and used by the public. A reasonable analogy for chronic disease research today would be the status of diarrhea research about 40 years ago, when such research was fragmented and of low impact. Led by the efforts of Bangladeshi institutions and support from the World Health Organization and others, oral rehydration therapy and related efforts initiated worldwide have markedly reduced childhood deaths from diarrhea. ${ }^{26}$

Priority research will involve developing a better understanding of the relationships among "known" risk factors, such as smoking, blood pressure and blood lipids, but also a better understanding of the complex interactions of obesity, diabetes, urbanization and vascular disease. Large-scale studies might well lead to better therapeutics with global relevance. There is every reason to believe that a major Asian-led effort to improve health research and development for the control of chronic disease, with support from global research and development partners, could be similarly effective in saving lives and reducing poverty in the 2ist century.

This article has been peer reviewed.

Competing interests: None declared.

Contributors: This article was originally conceived by Prabhat Jha. Both authors contributed to analyses, interpretation and writing.

Acknowledgements: Prabhat Jha is supported by the Li Ka Shing Knowledge Institute at St. Michael's Hospital, the University of Toronto and the Canada Research Chair Program. Zhengming Chen is supported by the Clinical Trial Service Unit and Epidemiological Studies Unit.

\section{REFERENCES}

I. Wolf M. What India must do to outpace China. Fin Times [New York] 2006 Feb I4.

2. Tandon A. Attaining millennium development goals in health: Isn't economic growth enough? no. 35 of Economics and Research Department policy brief series. Manila (Philippines): Asian Development Bank; 2005. Available: www.adb.org /Documents/EDRC/Policy_Briefs/PB035.pdf (accessed 2007 Sept 24).

3. Jha P, Anderson I. Reducing adult deaths from chronic diseases in Asia: evidence and opportunities. Washington: The World Bank Group, Disease Control Priorities Project; 2007. Available: http://www.dcp2.org/features/49 (accessed 2007 Sept 28).

4. Lopez $\mathrm{AD}$, Mathers $\mathrm{CD}$, Ezzati M, et al, editors. Global burden of disease and risk factors. Washington: World Bank Publications; 2006.

5. Jha P. Avoidable mortality in India: past progress and future prospects. Natl Med India 2002;15 Suppl I:32-6. 
6. Peto R. Statistics of chronic disease control. Nature I992;356:557-8.

7. Jamison DT, Measham AR, Breman JB, et al, editors. Disease control priorities in developing countries. 2nd ed. New York: Oxford University Press; 2006. Available: http://files.dcp2.org/pdf/DCP/DCPor.pdf (accessed 2007 Sept 24).

8. Jamison DT. Investing in health. In: Jamison DT, Measham AR, Breman JB, et al, editors. Disease control priorities in developing countries. 2nd ed. New York: Oxford University Press; 2006. p. 3-34. Available: http://files.dcp2.org/pdf/DCP /DCPor.pdf (accessed 2007 Sept 24).

9. Bobak M, Jha P, Nguyen S, et al. Poverty and smoking. In: Jha P, Chaloupka FJ, editors. Tobacco control in developing countries. Oxford: Oxford University Press; 2000. p. 4I-6I.

Io. Bonu S, Rani M, Jha P, et al. Household tobacco and alcohol use, and child health: an exploratory study from India. Health Policy 2004;70:67-83.

II. van Doorslaer E, O'Donnell O, Rannan-Eliya RP, et al. Effect of payments for health care on poverty estimates in II countries in Asia: an analysis of household survey data. Lancet 2006;368:1357-64

I2. Liu BQ, Peto R, Chen ZM, et al. Emerging tobacco hazards in China: I. Retrospec tive proportional mortality study of one million deaths. BMJ I998;3I7:I4II-22.

I3. Gajalakshmi V, Peto R, Kanaka TS, et al. Smoking and mortality from tuberculosis and other diseases in India: retrospective study of 43000 adult male deaths and 35000 controls. Lancet 2003;362:507-I5.

I4. Jha P, Chaloupka FJ, Moore J, et al. Tobacco addiction. In: Jamison DT, Measham $\mathrm{AR}$, Breman JB, et al, editors. Disease control priorities in developing countries. 2nd ed. New York: Oxford University Press; 2006. p. 869-85. Available: http://files.dcp2.org/pdf/DCP/DCP46.pdf(accessed 2007 Sept 24).

I5. Peto R, Lopez AD, Boreham J, et al. Mortality from smoking in developed coun tries, I950-2000. 2nd ed. Oxford (UK): Clinical Trial Service Unit and Epidemiological Studies Unit; 2006. Available: http://WwW.ctsu.ox.ac.uk/ tobacco/ (accessed 2007 Sept 24).

I6. Jha P, Ranson MK, Nguyen SN, et al. Estimates of global and regional smoking prevalence in 1995, by age and sex. Am J Public Health 2002;92:1002-6.
17. Institute of Medicine. Cancer control priorities in low and middle-income countries. Washington: National Academy of Sciences; 2007.

I8. Gaziano TA, Reddy KS, Paccaud F, et al. Cardiovascular disease. In: Jamison DT, Measham AR, Breman JB, et al, editors. Disease control priorities in developing countries. 2nd ed. New York: Oxford University Press; 2006. p. 645-62. Available: http://files.dcp2.org/pdf/DCP/DCPor.pdf (accessed 2007 Sept 24).

I9. Cholesterol, diastolic blood pressure, and stroke: 13,000 strokes in 450,000 people in 45 prospective cohorts. Prospective studies collaboration. Lancet 1995;346:1647-53.

20. Chen ZM, Jiang LX, Chen YP, et al; COMMIT (ClOpidogrel and Metoprolol in Myocardial Infarction Trial) Collaborative Group. Addition of clopidogrel to aspirin in 45852 patients with acute myocardial infarction: randomised placebo-controlled trial. Lancet 2005;366:I607-2I.

2I. Chen Z, Peto R, Collins R, et al. Serum cholesterol concentration and coronary heart disease in a population with low cholesterol concentrations. BMJ I991;303:276-82.

22. Rose G. Sick individuals and sick populations. Int J Epidemiol I985;I4:32-8.

23. Heart Protection Study Collaborative Group. MRC/BHF Heart Protection Study of cholesterol lowering with simvastatin in 20,536 high-risk individuals: a randomised placebo-controlled trial. Lancet 2002;360:7-22.

24. Chen Z, Lee L, Chen J, et al. Cohort profile: the Kadoorie Study of chronic disease in China (KSCDC). Int J Epidemiol 2005;34:1243-9.

25. Jha P, Gajalakshmi V, Gupta PC, et al. Prospective study of one million deaths in India: rationale, design, and validation results. PLoS Med 2006;3:er8.

26. Global IDEA Scientific Advisory Committee. Health and economic benefits of an accelerated program of research to combat global infectious diseases. CMAJ 2004;I7I:I203-8.

Correspondence to: Prof. Prabhat Jha, Centre for Global Health Research, St. Michael's Hospital, University of Toronto, Toronto ON M5C IN8; fax 4I6864 5256; prabhat.jha@utoronto.ca

\section{Canadian Medical Association}

\section{Special Awards - Call for Nominations}

The Canadian Medical Association invites nominations for the 2008 special awards.

- Medal of Honour

- F.N.G. Starr Award

- Medal of Service

- May Cohen Award for Women Mentors

- Sir Charles Tupper Award for Political Action

- Award for Excellence in Health Promotion

- Award for Young Leaders

- Dr. William Marsden Award in Medical Ethics

Refer to the "Awards from CMA" section on cma.ca for detailed criteria on each of the awards or contact the awards co-ordinator at $800663-7336 \times 2280$.

Nominations should be submitted to:

Chair, Committee on Archives and Awards

c/o Committee Co-ordinator

Corporate Affairs

Canadian Medical Association

1867 Alta Vista Dr.

Ottawa ON K1G 3 Y6

Closing date for receipt of nominations is Nov. 30, 2007.

\section{Association médicale canadienne}

\author{
Prix spéciaux pour l'an 2008 - Appel de candidatures
}

L’Association médicale canadienne sollicite des candidatures à ses prix spéciaux pour 1'an 2008.

- Médaille d'honneur

- Prix F.N.G. Starr

- Médaille de service

- Prix May-Cohen pour femmes mentors

- Prix Sir-Charles-Tupper d'action politique

- Prix d'excellence en promotion de la santé

- Prix des jeunes chefs de file

- Prix Dr-William-Marsden d'éthique médicale

Voir «Prix et distinctions de l'AMC» sur le site amc.ca pour les critères détaillés de chaque prix ou contacter la coordonnatrice des prix au $800663-7336$, poste 2280 .

Les candidatures doivent être soumises à la :

Présidente, Comité des archives et des distinctions a/s Coordonnatrice des comités

Affaires générale

Association médicale canadienne

1867, promenade Alta Vista

Ottawa (Ontario) K1G 3 Y6

Les candidatures doivent être présentées au plus tard le 30 novembre 2007.

\section{ASSOCIATION \$ CANADIAN \\ MÉDICALE \$ MEDICAL \\ CANADIENNE \&SSOCIATION}

